\title{
Cryoamputation: A Paradigm for Safe Emergency Medical Amputation and Immediate Local Infection Control without Antimicrobial Resistance Induction
}

\author{
Jose Pascual, ${ }^{1,2}$ Holly Rodgers, Jeremy Cannon,,2 Andrew Rogalski, and Lewis J. Kaplan ${ }^{1,2}$
}

\begin{abstract}
Background: Peripheral arterial disease may be complicated by tissue ischemia and subsequent gangrene. When tissue gangrene is accompanied by septic shock in a patient with comorbid medical conditions and compromised physiology, emergency operation may trigger cardiac complications of non-cardiac surgery. Such patients benefit from resuscitation and cardiac optimization prior to operative intervention.

Conclusion: Cryoamputation provides a non-surgical alternative to immediate amputation, arrests bacterial growth, has no known resistance induction, achieves anesthesia, and excludes ischemic tissue and its metabolic byproducts from the circulation. This allows patient resuscitation, metabolic abnormality correction, and cardiac performance optimization prior to definitive operation.
\end{abstract}

Keywords: cryoamputation; gangrene; limb ischemia

A 68-YEAR-OLD MALE with diabetes mellitus presented to the emergency department confused, obtunded, and with a foul-smelling left lower extremity with evidence of septic shock (temperature, $102.7^{\circ} \mathrm{F}$; heart rate, 128 beats per minute; blood pressure, $=76 / 42 \mathrm{~mm} \mathrm{Hg}$; respiration, 32/min; oxygen saturation, $87 \%$ on room air). There were no left foot Doppler signals; a weak signal was noted at the popliteal. The foot and distal lower extremity were crepitant with bullae and black discoloration. The contralateral foot evidenced stigmata of peripheral arterial disease. Airway control for obtundation was required.

Laboratory profiling revealed hyperglycemia (glucose $=$ $486 \mathrm{mg} \%$ ), acute kidney injury (serum creatinine $=3.9 \mathrm{mEq} / \mathrm{L}$ ), anemia $(\mathrm{Hgb}=7.3 \mathrm{gm} \%)$ and thrombocytopenia (platelets $=$ 62,000 ). The initial arterial blood gas was 7.02/22/54. An electrocardiogram showed lateral ischemia and an echocardiogram revealed an ejection fraction of $20 \%$ with global hypokinesis. Empiric antibiotic agents (vancomycin, piperacillin-tazobactam, and clindamycin) were administered after obtaining cultures.
Vasopressors were required to support mean arterial pressure. The working diagnosis was septic shock from extremity gangrene.

\section{Case Presentation}

The patient presented a nearly insurmountable risk for general anesthesia. Therefore, cryoamputation was selected for acute control of his septic process to allow for resuscitation prior to definitive surgical therapy. The specific technique utilized is detailed in Table 1 and demonstrated in Figs. 1-3.

\section{Outcome}

The affected limb was frozen and the patient stabilized over the next 48 hours including an increase in cardiac performance, elimination of vasopressin, and reduction of norepinephrine dosing. His metabolic abnormalities were corrected and he was successfully definitively operated on

\footnotetext{
${ }^{1}$ Perelman School of Medicine, University of Pennsylvania, Philadelphia, Pennsylvania.

${ }^{2}$ Corporal Michael J. Crescenz VA Medical Center, Philadelphia, Pennsylvania.
}

(C) Jose Pascual et al. 2017; Published by Mary Ann Liebert, Inc. This Open Access article is distributed under the terms of the Creative Commons License (http://creativecommons.org/licenses/by/4.0), which permits unrestricted use, distribution, and reproduction in any medium, provided the original work is properly credited. 
Table 1. Steps for Safe Cryoamputation of an Extremity

\begin{tabular}{|c|c|c|}
\hline Steps in cryoamputation & Rationale & Equipment \\
\hline Informed consent & $\begin{array}{l}\text { Temporary freezing that requires formal } \\
\text { amputation }\end{array}$ & \\
\hline Limb protection & Prevents dry ice from adhering to tissue & Biohazard bag (Fig. 1) \\
\hline Proximal tourniquet & $\begin{array}{l}\text { Placed just above affected tissue to } \\
\text { impede venous outflow of bacteria, } \\
\text { toxins and cooling blood }\end{array}$ & $\begin{array}{l}\text { Non-latex tourniquet or similar product; } \\
\text { two may be required for large limbs }\end{array}$ \\
\hline $\begin{array}{l}\text { Place limb in styrofoam } \\
\text { cooler }\end{array}$ & $\begin{array}{l}\text { Enclosed environment for dry ice to } \\
\text { reduce evaporation and preserve } \\
\text { temperature, protects medical } \\
\text { personnel and patients unaffected limb }\end{array}$ & $\begin{array}{l}\text { Styrofoam cooler with aperture in one } \\
\text { side (Fig. 2) }\end{array}$ \\
\hline Fill box with dry ice & Cryoamputates affected limb & $\begin{array}{l}\text { Dry ice, dry ice gloves (gauntlet style)- } \\
\text { personnel must be protected from dry } \\
\text { ice injury }\end{array}$ \\
\hline $\begin{array}{l}\text { Circumferential } \\
\text { warming pad wrap } \\
\text { of healthy tissue }\end{array}$ & $\begin{array}{l}\text { Prevents inadvertent ascending freezing } \\
\text { of viable residual limb }\end{array}$ & $\begin{array}{l}\text { Warming blanket, Arctic Sun }{ }^{\circledR} \\
\text { Temperature Management System } \\
\text { (Bard Medical Division, Covington, } \\
\text { GA) or other warming capable device }\end{array}$ \\
\hline Secure dry ice cooler & $\begin{array}{l}\text { Reliable supply of dry ice to maintain } \\
\text { freezing }\end{array}$ & $\begin{array}{l}\text { Specialty dry ice cooler; a rigid walled, } \\
\text { styrofoam insulated cooler may be } \\
\text { substituted }\end{array}$ \\
\hline Hourly assessment of pain & $\begin{array}{l}\text { Freezing also impacts nocioception } \rightarrow \\
\text { stepwise reduction in analgesics are } \\
\text { required to avoid excess administration }\end{array}$ & Pain assessment tools \\
\hline $\begin{array}{l}\text { Establish a guiding policy } \\
\text { and protocol }\end{array}$ & $\begin{array}{l}\text { Rarity of the procedure renders a guide } \\
\text { critical in ensuring safe utilization }\end{array}$ & $\begin{array}{l}\text { Multi-professional input in policy and } \\
\text { protocol creation }\end{array}$ \\
\hline
\end{tabular}

without incident 72 hours after emergency department admission. Importantly, antibiotics were stopped 24 hours post-operative because surveillance cultures at 48 hours after cryoamputation were sterile.

Critical limb ischemia afflicts approximately $12 \%$ of the U.S. population older than age 50. Additionally, at least $50 \%$ of amputations are related to peripheral arterial disease, and in particular diabetes mellitus [1,2]. One devastating complication of this disease such as in our patient is extremity

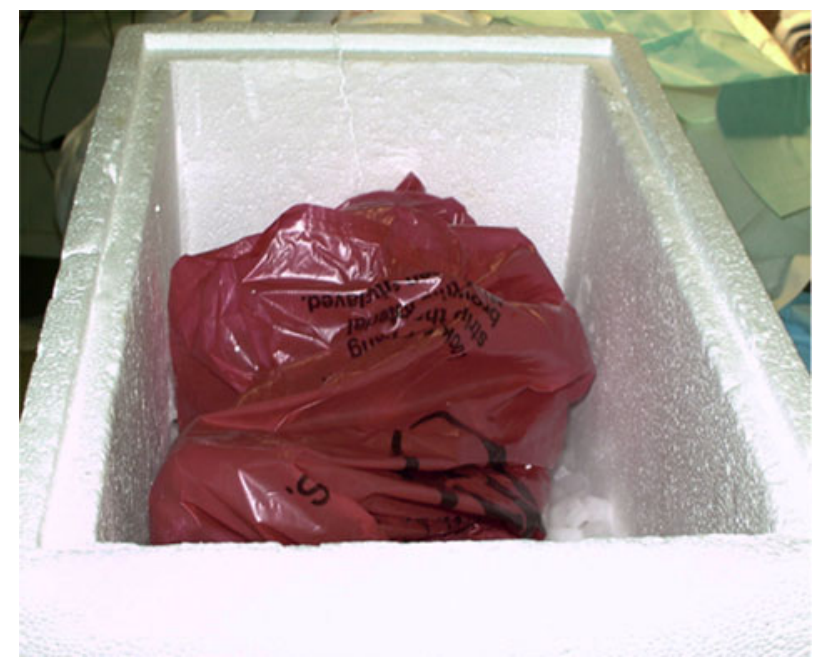

FIG. 1. Positioning the limb for cryoamputation within the cooler. A view from the patient's head toward the foot. Note that the limb to be cryoamputated is encased in a plastic biohazard bag. The limb also rests on top of a bottom layer of dry ice. tissue ischemia that progresses to gangrene. Tissue invasion with bacteria from a pre-existing ulcer, often including Pseudomonas, accompanies tissue ischemia and promotes gangrene. The clinician may be presented with difficult management decisions when the patient requires extremity amputation to clear the infection and necrotic tissue, but suffers from concomitant critical illness related to the systemic effects of septic shock.

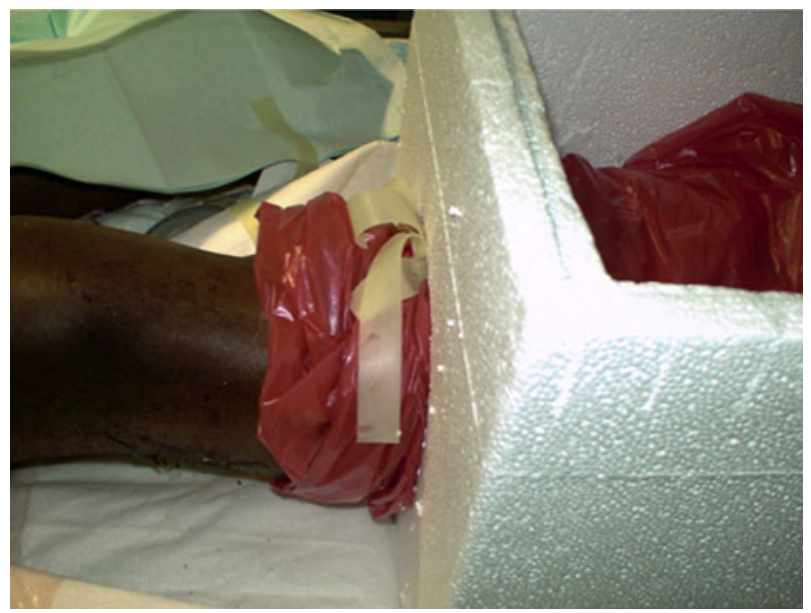

FIG. 2. The side aperture for transmitting the limb for cryoamputation. Note that the limb to be cryoamputated is inserted into the cooler through a hole cut into the side of the cooler. A limb tourniquet is placed over the biohazard bag and tightened at the desired limb level for cryoamputation. A warming pad is to be placed proximal to the tourniquet to prevent inadvertent freezing of the remaining viable residual limb. 


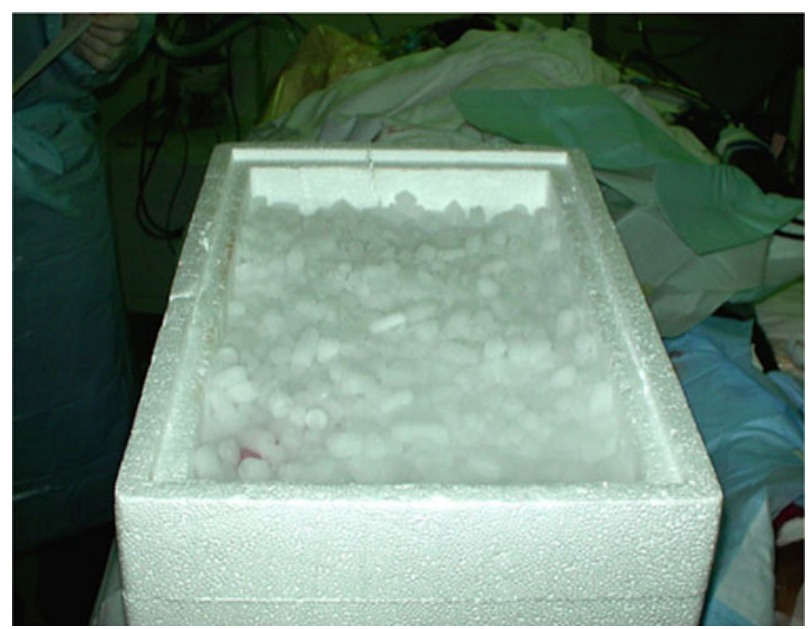

FIG. 3. View from the foot of the patient with the limb encased in dry ice. A view toward the patient's head. Note that the limb is now completely encased in dry ice and the level is below that of the lid rest. The cooler is now ready to be covered with the lid to reduce the rate of dry ice evaporation. The warming blanket protecting the proximal limb is not visible from this view.

Resuscitation, antibiotic administration, and source control are all required in parallel to achieve optimal survival [3]. Because it is generally unsafe to administer a general anesthetic to an unstable patient, a non-surgical option to achieve amputation, arrest bacterial growth, and isolate the gangrenous tissue from the systemic circulation would be an ideal temporary resuscitative measure. However, such an approach must also avoid promoting bacterial resistance by prolonging antibiotic duration.

Cryoamputation is one such solution and is a relatively uncommon technique that is invaluable for emergency, nonsurgical amputation [4]. This technique dates back to 1937 when Allen et al. [5,6] evaluated tissue asphyxia and temperature changes with the use of ligation and refrigeration in relation to local infection. This produced a halting of the metabolic process causing a "genuine hibernation of cells." They surmised that once this undertaking has begun, the limb must be amputated, otherwise fatal toxins from the infected limb are released into circulation with re-warming. Allen et al.'s [5,6] animal research helped establish the foundation and basic principles for cryoamputation. Dry ice for extremity cryoamputation was not introduced into medical practice until 1960, offering the advantages of rapidly freezing a limb while avoiding the difficulties inherent in wet ice such as inconsistent tissue temperature and skin maceration [7].

Appropriate patients for cryoamputation are critically ill with systemic signs of toxicity including but not limited to hypotension, tachycardia, metabolic acidosis, and acute multi-organ failure. This technique combines metabolic arrest with anesthesia of the ischemic tissue bed; efficacious analgesia is difficult with ischemic extremities prior to nerve death. Cryoamputation retards rhabdomyolysis thereby preventing myoglobinuria and diminishing the risk of acute kidney injury (AKI) [4]. Despite the plethora of advantages, cryoamputation is infrequently utilized in the critical care arena.

Because cryoamputation freezes tissues, it is irreversible and requires informed consent. As the procedure is not without its own risks, herein we have described a standardized method of performing cryoamputation targeted to reduce and mitigate against medical errors potentially associated with this infrequently performed but life-saving procedure. To the best of our knowledge, no single English language article (prior to this one) marshals all of these elements in a single document that may be translated directly into clinical practice. Improved outcomes using cryoamputation stem in part from limiting the anesthetic exposures sustained by patients with multiple medical comorbidities. Including cryoamputation as one of a number of improvements in peri-operative care, a number of authors have reported a reduction from the once high $40 \%$ mortality rate for emergency extremity amputation in acutely ill patients to a mortality rate less than $10 \%[4,8]$.

Unexplored is the potential to reduce antibiotic duration and resistance selection pressure in this subset of patients for whom antimicrobial therapy, including antifungal therapy, is often prolonged. Our patient had a four-day course of antibiotics, aided by rapid source control using a mechanism to which there is no resistance-freezing-followed by surgical removal of the infected tissue. This time frame is consistent with the excellent outcomes noted in the Study to Optimize Peritoneal Infection Therapy (STOP-IT) trial that compared four to eight days of antibiotic therapy [9]. Such an advantage may be key in resource-limited environments in which antibiotic agents are difficult to secure, allowing for the available supply to meet more patients' needs by reducing days of administration and supporting efforts to reduce bacterial resistance. Furthermore, as multi-drug resistance continues to be more prevalent, charging global campaigns for antibiotic stewardship, cryoamptuation may provide a means of addressing source control for patients whose pathogen has limited to no antibiotic sensitivity [10].

\section{Conclusions}

Cryoamputation is an effective technique to perform emergency amputation in a critically ill, septic patient. The process provides rapid, temporary source control but must be followed by a formal amputation because of the irreversible effects of tissue freezing. Although effective, cryoamputation is not without risks to the patient and provider. Cryoamputation offers the potential benefit of reducing antimicrobial utilization by achieving rapid source control in a fashion to which there is no resistance. A formal protocol and appropriate equipment allow this relatively rarely used technique to be safely utilized in the intensive care unit.

\section{Acknowledgment}

H.R., A.R., and L.K. are federal employees and the views or opinions expressed in this article are not to be taken as official government statements of position or policy.

\section{Author Disclosure Statement}

No competing financial interests exist.

\section{References}

1. Davies MG. Critical limb ischemia: Epidemiology. Methodist Debakey Cardiovasc J 2012;8:10-14. 
2. Thiruvoipati T, Kielhorn CE, Armstrong EJ. Peripheral artery disease in patients with diabetes: Epidemiology, mechanisms, and outcomes. World J Diabetes 2015;6:961-969.

3. Angus DC, Barnato AE, Bell D, et al. A systematic review and meta-analysis of early goal-directed therapy for septic shock: The ARISE, ProCESS and ProMISe Investigators. Intensive Care Med 2015;41:1549.

4. Winburn GB, Wood MC, Hawkins ML, et al. Current role of cryoamputation. Am J Surg 1991;162:647-651.

5. Allen FM. Local asphyxia and temperature changes in relation to gangrene and other surgical problems. Trans Assoc Am Physicians 1937;52:189-194.

6. Allen FM. Experiments concerning ligation and refrigeration in relation to local intoxication and infection. Surg Gynec Obstet 1939;68:1047-1051.

7. Hunsaker RH, Schwartz JA, Keagy BA, et al. Dry ice cryoamputation: A twelve year experience. J Vasc Surg 1985; 2:812-816.

8. Brinker MR, Timberlake GA, Goff JM, et al. Below-knee physiologic cryoanesthesia in the critically ill patient. J Vasc Surg 1988;7:433-438.

9. Sawyer RG, Claridge JA, Nathens AB, et al. Trial of shortcourse antimicrobial therapy for intra-abdominal infection. N Engl J Med 2015;372:1996-2005.

10. Sartelli M, Labricciosa FM, Barbadoro P, et al. The Global Alliance for Infections in Surgery: Defining a model for antimicrobial stewardship-Results from an international cross-sectional survey. World J Emerg Surg 2017;12:34.
Address correspondence to:

Dr. Lewis J. Kaplan

Perelman School of Medicine University of Pennsylvania Surgical Critical Care

Corporal Michael J. Crescenz. VA Medical Center 3900 Woodland Avenue Philadelphia, PA 19104

E-mail: Lewis.Kaplan@uphs.upenn.edu

\begin{tabular}{rl|} 
Abbreviations Used \\
AKI $=$ acute kidney injury \\
STOP-IT $=$ Study to Optimize Peritoneal Infection \\
Therapy trial \\
U.S. $=$ United States
\end{tabular}

Cite this article as: Pascual $\mathrm{J}$, Rogers $\mathrm{H}$, Cannon $\mathrm{J}$, Rogalski A, Kaplan LJ (2017) Cryoamputation: A paradigm for safe emergency medical amputation and immediate local infection control without antimicrobial resistance induction. Surgical Infections Case Reports 2:1, 109-112, DOI: 10.1089/crsi.2017.0031 